\title{
Fundamentalisme Agama:
}

\section{Antara Fenomena Dakwah dan Kekerasan \\ Atas Nama Agama}

\author{
Fahrurrozi Dahlan \\ IAIN Mataram \\ E-mail: roziqi_iain@yahoo.co.id
}

\begin{abstract}
Fundamental Islam is a religious view that has its roots in orthodox understanding who interpret the religious texts in rigid, static and exclusive ways. Fundamentalism involves efforts to purify or reform the beliefs and practices of the followers according to their principles. The study of fundamentalism is a part in diversity in understanding a religion which has its own characteristics, not least reflected in their interpretation of the doctrine of rigid and literalist religion. This is motivated by several factors including; interpretation as it is important for them to maintain the purity of doctrine and practice. Next characteristic that the application of the doctrine as a whole is the only way to save mankind from ignorance. The conclusion of this study is the rise of fundamentalism in Islam, is actually a strong reaction on the growth of Islamic liberalism.
\end{abstract}

\section{Kata Kunci:}

Fundamentalisme, Dakwah, Kekerasan Atas Nama Agama

\section{A. Pendahuluan}

Bassam Tibi pernah menyinggung tentang kekagumannya terhadap Islam di Indenesia. Menurut Tibi, Indonesia dapat menjadi jantung Islam yang menentukan mainstream peradaban Islam. Ini dikarenakan Islam di Indonesia adalah Islam yang mempraktikkan toleransi, pluralisme, dan pandangan terbuka para pengikutnya, sebuah kondisi yang susah ditemukan di saudara-saudara mereka di Timur Tengah. Kendati demikian, Indonesia juga menyimpan bara 
fundamentalisme yang dapat membakar setiap saat. Meski juga Tibi menyebut bahwa para kaum fundamentalis tersebut tidaklah berbahaya selama berada di pinggiran kekuasaan dan tidak masuk dalam lingkaran kekuasaan dan selama pandangan absolutis-arabosentris mereka menjadi preferensi publik Indonesia (Tibi, 2000: 84).

Seseorang tidak akan bisa menghindari label apabila membicarakan tentang sesuatu, dan ia tidak akan bisa memahami sebuah kawasan seluas dan sekompleks dunia muslim kecuali ia menganalisis berbagai fenomena ke dalam kategori yang bisa dipertanggungjawabkan. Karena itu, pertanyaannya bukan berkaitan dengan ia bisa menggunakan label itu atau tidak, tetapi adalah bagaimana sehrusnya ia menggunakan label (Jainuri, 2003: 4).

Beberapa sarjana tidak setuju istilah fundamentalisme diterapkan untuk Islam, karena elemen-elemen lokal dari tempat istilah itu muncul sangat mewarnai makna istilah tersebut, yang selanjutnya sulit diterapkan ditempat lain.

Dalam konteks ini, Shepard menegaskan bahwa penggunaan istilah fundamentalisme sering mengalami persoalan disebabkan oleh:

1. Digunakan tanpa makna yang jelas.

2. Sebenarnya cocok untuk kasus tertentu tetapi kemudian digunakan untuk fenomena yang berbeda dan luas.

3. Terutama adanya value judgment terhadap istilah tersebut (Shepard, 1987: 5).

\section{B. Fundamentalisme}

Istilah fundamentalis bagi Esposito terasa lebih provokatif dan bahkan pejoratif sebagai gerakan yang pernah dilekatkan pada Kristen sebagai kelompok literlis, statis dan ekstrem. Pada gilirannya fundamentalisme sering merujuk kepada kehidupan masa lalu, bahkan lebih jauh lagi fundamentalisme sering disamakan sebagai ekstrimisme, fanatisme politik, aktivisme politik, terorisme dan Anti Amerika. Karena itu, John L. Esposito lebih memilih menggunakan istilah revivalisme (kebangkitan) Islam atau aktivisme Islam yang memiliki akar tradisi Islam (Esposito, 1992: 7-8). 
Istilah fundamentalis bukan berasal dari terminologi Islam, tetapi berasal dari kata bahasa Inggris yaitu fundament. Sebuah terminologi yang lahir dalam konteks sejarah keagamaan di dunia kristen Amerika Serikat. Disebutkan bahwa fundamentalisme lahir dalam situasi konflik antar budaya urban dan budaya pedesaan di Amerika pasca PD I, yang muncul bersamaan dengan situasi depresi nilai-nilai agraris dalam proses industrialisasi dan urbanisasi. Bentuknya yang agresif sering muncul di daerah yang terisolasi dan hanya sedikit saja yang mendapat simpati kalangan kota. Fundamentalisme merupakan gerakan reaksi terhadap pola peradaban yang timbul dari proses industrialisasi dan urbanisasi. Aliran fundamentalisme di Amerika melawan arus pemikiran ilmiah yang mendasarkan diri pada penalaran dan arus sekulerisme (Harahap, 1997: 238).

Membaca fenomena fundamentalisme Amerika ini. Yusril Ihza mengatakan dua ciri yang ditunjukkan mereka adalah cenderung menafsirkan teks-teks keagamaan secara rigid (kaku) dan literal (harfiah) (Mahendra, 1993: 6-7). Dua ciri ini berimplikasi pada sikap mereka yang sering kali fundamentalis, militan, dan berfikiran sempit, bersemangat secara berlebihan (ultra-zealous) atau cenderung ingin mencapai tujuan dengan cara-cara memakai kekerasan (Raharjo, 1993: 2).

\section{Sejarah Kemunculan Islam Fundamentalis}

Menilik fakta sejarah Islam, memang dapat dijumpai adanya kelompok-kelompok dalam Islam yang berpandangan fundamentalis fundamentalisis, walaupun tidak sepenuhnya muncul sebagai reaksi terhadap modernisasi, melainkan juga karena latar belakang politik dan teologi. Dalam bidang teologi misalnya ada Khawarij, kelompok ini muncul sebagai reaksi terhadap sikap khalifah Ali Bin Abi Thalib dan Muawiyah serta para pendukungnya dari tokoh yang bertikai ini mengambil jalan penyelesaian dengan cara arbitrase (damai) yang berakhir dengan kemenangan dari pihak Muawiyah. Kelompok ini kemudian menuduh orang-orang yang terlibat dalam arbitrase sebagai kafir (Nata, 2001: 19). Kaum khawarij percaya bahwa perintah al-Qur'an untuk "amar ma'ruf dan nahi mungkar" harus dilaksanakan dengan cara ketat, harfiah, dan tanpa pengecualian. Dunia khawarij hanya terbagi 
menjadi dua; iman dan kafir, muslim dan non muslim (musuh Tuhan), damai dan perang. Setiap tindakan yang tidak sesuai dengan hukum merupakan suatu dosa besar. Para pendosa dihukum kafir dan dikeluarkan dari komunitas beriman (takfir). Para pelaku dosa besar tidak cuma dipandang sebagai pelanggar hukum agama tetapi sebagai orang yang murtad, bersalah karena pengkhianatan dan pantas dihukum mati, kecuali jika mereka bertaubat (Esposito, 2002: 52).

Fazlurrahman menggambarkan reaksi-reaksi kalangan fundamentalis terhadap kaum liberal Islam atau sebutan lain untuk kaum modernis. Gerakan fundamentalisme ini yang disebut Fazlurrahman sebagai gerakan revivalis, berawal dengan hadirnya gerakan revivalis pra-modernis, terutama lewat gerakan Ibn Abd alWahab (Wahabiyah), yang oleh Fazlurrahman (1979) digambarkan sebagai denyut pertama kehidupan Islam, setelah mengalami kemorosotan beberapa abad sebelumnya. Untuk pertama kali setelah lima abad sebelumnya, Ibn Taimiyah (w. 1328) berjuang sendirian, gerakan ini pun mengambil jalan fundamentalis. Yakni, mempersoalkan tradisi Islam yang hidup dengan jalan mengkonfrontasikannya pada sumber-sumber asli Islam.

Di Indonesia, gerakan revivalis awal ini bolehlah dirujuk pada gerakan Padri di Minangkabau, sekitar abad XIX. Gerakan ini merupakan gerakan pra-modernis pertama di Indonesia, yang berakar dalam gerakan Tuanku Nan Tao, dan khususnya lagi setelah kembalinya "tiga haji" dari Tanah Suci Makkah, yakni Haji Miskin, Haji Sumanik, Haji Piabang (Rahman, 2001: 432).

\section{Karakteristik Islam Fundamentalis}

Fazlurrahman memberikan identifikasi gerakan Islam fundamentalis sebagai berikut:

Pertama, bentuk keperihatinan yang mendalam atas kemerosotan moral dan social masyarakat muslim.

Kedua, menghimbau kepada kaum muslim untuk kembali kepada Islam yang orisinal, yang murni (salafiyah), dengan meninggalkan takhayul-takhayul. 
Ketiga, menghimbau untuk membuang beban yang menghancurkan berupa pandangan tentang takdir dari "agama rakyat", dan teologi asy'ariyah yang berpengaruh di mana-mana.

Keempat, perlunya melakukan pembaruan yang dipelopori kaum fundamentalis melalui jihad sekalipun, kalau itu dianggap perlu (Fazlurrahman, 1979: 23).

Sementara itu, lebih lanjut Rahman (2001: 437-440) menambahkan ciri-ciri khas kaum fundamentalis adalah:

Pertama; penafsiran refresif atas nama Tuhan. Seperti diketahui bahwa, agama itu sendiri terdiri atas simbol-simbol yang bisa dimaknai dengan pandangan idologi dan politik tertentu. Misalnya pesan keagamaan bisa menjadi justifikasi untuk paham-paham modern seperti demokrasi, kesamaan, kebebasan dan humanism. Tetapi sebaliknya, pesan keagamaan yang sama juga bisa dipakai untuk membenarkan segala perbedaan dan diskriminasi dalam klas, ras, seks, gender, agama, pendidikan, keyakinan politik, justru mengatasnamakan Tuhan. Yang terakhir ini terjadi pada kalangan yang disebut fundamentalisme. Fundamentalisme Islam secara ekstrim bisa menjadi contoh penafsiran refresif atas nama Tuhan, dengan otoritas obsolutnya.

Kedua; kesatuan agama dan negara. Ciri yang paling mencolok dari fundamentalisme Islam dalam konteks hubungan Negara dan agama adal. obah tekanan yang sangat kuat untuk membangun bentuk negara teokratik (khilafah, atau sejenisnya). Negara ideal yang ditegakkan dalam pandangan kaum fundamentalis Islam ini, dengan jalan menyatukan negara (state) dan agama (religion). Isu-isu pokok yang dikedepankan adalah penerapan syari'at dengan memperbesar peran ulama'.

Ketiga; penyebaran simbol-simbol kejahatan. Karena kalangan fundamentalis tidak bisa menyatukan Islam dengan tantangan Barat dan apa yang datang dari Barat dianggap sebagai "jahat, dosa bahkan iblis".

Keempat; literalisme-skriptual. Juga penololakan historisisme dan rasionalisasi. Ini adalah tipikal dari cara pandang kaum fundamentalis yang menolak cara membaca kitab suci dari kalangan "Islam Liberal" yang mempertimbangkan situasi dan perubahan social. Kaum fundamentalis menolak penafsiran baru atas teks Islam, yang 
dianggapnya menyimpang dari "Islam yang murni". Seluruh problem sekarang dipecahkan dengan cara kembali kepada zaman awal Islam yang ideal itu.

Kelima; obsesi atas isu-isu superstruktur. Islam fundamentalis menolak kategori-kategori kelas, kepentingan-kepentingan kelas, pembentukan kelas dan organisasi kelas yang biasa dipakai dalam sosiologi.

Keenam; Pan-Islamisme. Obsesi pokok yang dikembangkan oleh Islam Fundamentalis adalah perluasan dari konsep ummah (komuitas orang beriman), yang diberikan definisi secara ideologis.

Ketujuh; patriarkhi. Mengembalikan peran wanita ke sector domistik dari sektor publik, mewajibkan jilbab secara ketat dan rigid.

Kedelapan; tidak Timur dan tidak Barat. Selogan utama yang disuarakan oleh kaum fundamentalis yang dikutip dari al-Qur'an, tetapi diberikan muatan interpretasi secara politis dan ideologis, dengan maksud Timur (Komunis), Barat (kapitalis).

Kesembilan; otoritarian dalam wacana. Dalam hal wacana, kalangan fundamentalis bersikap lebih penting menekankan pada apaapa yang normative daripada statemen-statemen diskriptif-faktual. Fundamentalisme terkadang memiliki suatu program atau pandangan dunia (world view) tersendiri. Kaum fundamentalis berupaya kuat untuk menjadikan tatanan tersebut menjadi pengganti dari tatanan yang sudah ada.

\section{E. Pemikiran dan Gerakan Fundamentalisme Agama}

\section{Pemikiran Islam Fundamentalis}

Para fundamentalis telah kehilangan kesabaran terhadap atau menolak para modernis. Ada garis halus yang sering dilanggar antartradisionalis yang kita sebut fundamentalis (pada kepercayaan dan imannya). Perbedaannya terdapat pada strategi dan gaya mereka. Strateginya dijelaskan tidak lebih dari filsafat politik, karakter personal, usia, dan gaya hidup turut membedakan perbedaan ini. Banyak fundamentalisis yang bukan dari kalangan cendikiawan, dan parahnya ingin mengimplementasikan tatanan Islam melalui kekuatan bersenjata 
dan konfrontasi. Biasanya mereka terdorong oleh kebencian clan rasa jijik pada apa yang mereka sebut "Barat". Mereka membangkitkan kemarahan dan kebencian di kalangan muslim. Retorika mereka mengandung banyak`statemen populis dan dorongan untuk berbuat tindakan anarkis. Mereka ini bukanlah figur-figur kharismatik dan seringkali ditolak (Ahmed, 194: 168).

Golongan fundamentalis memandang rendah para modernis, karenanya tidak jarang para modernis mengkategorikan mereka sebagai fundamentalis. Sebagian besar sarjana Barat, termasuk sarjana dari generasi muda, ditolak pula oleh golongan fundamentalis karena dinilai telah tercemari oleh kajian/pemikiran ala orientalisme (Ahmed, 194: 169). Itu sebabnya Fazlur Rahman mendefinisikan sikap pemikiran mereka sebagai "fundamentalis posmodernis" atau "neo fundamentalis" dan menggarisbawahi adanya sikap mereka yang anti Barat (Fazlurrahman, 1984: 134).

\section{Gerakan Islam Fundamentalis}

Menurut Marty dan Appleby, sebagai gerakan, fundamentalisme dan fundamentalis ditandai oleh sikap yang melawan atau berjuang (fight ). Di antaranya adalah melawan kembali (fight back) kelompok yang mengancam keberadaan mereka atau identitas yang menjadi taruhan hidup. Mereka berjuang untuk (fight for) menegakkan cita-cita yang mencakup persoalan hidup secara umum, seperti keluarga atau institusi sosial Iainnya. Kaum fundamentaiis berjuang dengan (fight with) kerangka nilai atau identitas tertentu yang diambil dari warisan masa lalu maupun konstruksi baru. Untuk itu mereka berjuang melawan (fight against) musuh-musuh tertentu yang muncul dalam bentuk komunitas atau tatanan sosial keagamaan yang dipandang menyimpang. Terakhir kaum fundamentalis juga dicirikan oleh perjuangan atas nama (fight under) Tuhan atau ide-ide lainnya (Martion dan Appleby, 1993: 25).

Di dalam rumusan Marty dan Appleby tentang fundamentalisme, tampak adanya kemiripan-kemiripan tertentu yang menyerupai ciriciri fundamentalisme. Di samping lima jenis perlawanan, Marty dan Appleby juga melihat bahwa gerakan ideologis gerakan fundamentalisme memiliki logika tersendiri. Terdapat kecenderungan kuat di kalangan fundamentalis untuk menolak berpikir historis dan 
hermeneutis dalam memahami kitab suci. Gerakan ini juga bersifat ekslusif dengan cara menarik garis tegas antara kelompoknya dengan kelompok lain. Hal ini semakin diperjelas dengan dianutnya identitasidentitas khusus lainnya, baik dalam hal penampilan fisik atau cara berpakaian yang membedakan diri mereka dari kelompok lain. Masalahnya kemudian sejauh mana kriteria fundamentalisme untuk dapat digunakan untuk menjelaskan fenomena keagamaan dalam tradisi agama tertentu? Apakah setiap agama pernah mencatat kehadiran "fundamentalisme agama" ataukah bentuk keberagamaan tersebut hanya ada dalam tradisi agama tertentu? Pertanyaanpertanyaan tersebut menjadi relevan untuk dikedepankan. Hal itu dimaksudkan agar tidak terjadi generalisasi yang berlebihan terhadap fenomena "kebangkitan agama" dan untuk melihat persoalan fundamentalisme secara Iebih proporsional serta kontekstual.

Muncul pertanyaan menggelitik, kenapa gerakan fundamentalisme selalu membenci dan memusuhi Barat dalam hal ini Amerika? Banyak faktor yang melatari, terutama; pertama, Amerika seringkali merupakan musuh sekunder dalam perananinya sebagai mitra dagang dan aliansi politik. Amerika memiliki kepentingan yang tertanam dalam memojokkan stabilitas rezim-rezim di seluruh dunia. Hal ini seringkali menempatkan Amerika pada posisi yang tidak menyenangkan karena menjadi pembela dan promotor pemerintah-pemerintah sekuler, sehingga mereka dianggap sebagai musuh utama oleh lawan-lawan. Kedua, secara langsung maupun tidak, ia telah mendukung kultur modern dalam sebuah dunia di mana orang-orang desa yang berada di pojok-pojok dunia di mana telah memiliki akar kultural pada MTV, filmfilm Hollywood, internet, dan sejumlah media yang berisi gambaran nilai-nilai yang diproyeksikan secara global oleh Amerika.

Ketiga, berkaitan dengan "penghinaan" hegemoni Amerika adalah pada aspek ekonomi, meskipun sebagian besar kerjasama perdagangan internasional bersifat multinasional dengan ikatan-ikatan personal dan legal lebih dari satu negara, tetapi kebanyakan berbasis di Amerika atau memiliki asosiasi-asosiasi di Amerika.

Keempat, masa depan yang hitam dan menakutkan bagi Islam adalah dominasi global dan kultur Amerika. Amerika dalam komando George W. Bush terdapat milisi-milisi sayap kanan yang yakin bahwa 
"tatanan dunia baru" yang diproklamirkan lebih sebagai modus kerjasama global. la merupakan sebuah komplotan konspirasional untuk mengendalikan dunia. Itu sebabnya, kaum fundamentalisis sangat menentang penjajahan/dominasi Amerika secara tidak langsung terhadap suatu negara sekaligus mengadakan perlawanan terhadap suatu negara di mana negara tersebut diinterfensi oleh Amerika. Sekedar menyebut contoh, Irak, Taliban, Afganistan, bahkan Indonesia, masuk dalam Iingkaran tersebut.

Melihat kondisi memprihatinkan seperti itu, kaum fundamentalisis justru akan mempergunakan momentum tepat pada keterlibatan suatu negara dalam menginterfensi negara lain dalam berbagai bidang dengan melihat beberapa tahapan sebagai berikut; (1) tahapan pertama, melibatkan sebuah krisis kepercayaan (crisis of confidence) menyangkut otoritas suatu rejim atau kebijakankebijakannya, (2) tahapan kedua, konflik legitimasi (conflict of legitimacy) yang di dalamnya terdapat kelompok yang menentang sikap untuk mempertanyakan legitimasi dari sebuah sistem pemerintahan, dan (3) tahapan ketiga, adanya sebuah legitimasi yang penuh. Pada tahap ini, kelompok yang menentang, berupaya memperluas permusuhannya terhadap setiap orang dalam suatu masyarakat yang diasosiasikan dengan sehuoh rezim yang dianggap tidak sah (illegitimate).

\section{F. Titik Kelemahan Islam Fundamentalis}

Pada dasarnya, teks-teks Islam mengajak umat Islam untuk berlaku moderat dan menolak serta menentang segala bentuk ekstrimisme atau "al-guluw" (melampaui batas), "tanaththu"' (keberagamaan yang terlalu ketat), "tasyaddud" (kekakuan dan terlalu berlebihan). Semua peringatan terhadap ekstrimisme dan sikap berlebih-lebihan ini adalah sebuah keniscayaan, karena dalam kecenderungan itu sendiri terdapat kelemahan- kelemahan serius yang inheren di dalamnya, diantaranya;

Kelemahan pertama, adanya sikap berlebih-lebihan. Padahal sikap tersebut tidak sesuai dengan hakikat alami manusia. Jika segelintir manusia saja tidak mampu menghilangkan sikap melampaui batas pada 
dirinya, dalam waktu singkat mayoritas manusia tidak akan mampu melakukannya.

Kelemahan kedua, bahwa yang melampaui batas itu tidak akan bertahan lama, karena kapasitas manusia untuk bertahan dan bersabar secara alami terbatas, karena manusia dapat dengan mudah menjadi bosan, ia tidak mampu menahan praktik melampaui batas dalam waktu yang lama.

Kelemahan ketiga, praktik berlebih-lebihan akan membahayakan hak-hak dan kewajiban-kewajiban lain. Sebuah ungkapan orang bijak mengatakan "setiap orang yang keterlaluan bagaimanapun akan berdekatan dengan hak yang hilang" (Qardhawi, 2001: 319-320).

Selanjutnya sebagai sebuah kelompok, mereka tampak memiliki ikatan solidaritas yang cukup solid, kokoh, militan, dan rela menerima resiko dari sebuah perjuangan. Namun, bersamaan dengan itu, terdapat beberapa catatan yang menyebabkan kaum fundamentalisme atau fundamentalisme dapat dikatakan kurang memperhatikan sikap yang kurang baik sekaligus menampakkan kelemahannya sendiri sebagai berikut;

Pertama, dari segi keyakinan, mereka bersikap rigid dan literalis. Kaum fundamentalis sangat menekankan simbol-simbol keagamaan dari pada substansinya. Mereka menganggap bahwa doktrin agama telah mengatur segala-galanya. Agama dinilainya sebagai sebuah sistem yang lengkap dan mencakup pula pelbagai subsistem di dalamnya. Mereka berbeda dengan pandangan kaum modernis yang pada umumnya kurang mementingkan soal istilah simbol-simbol yang bercorak distinktif. Bagi kaum modernis yang penting adalah bagaimana agar prinsip-prinsip, cita-cita, dan ruh Islam dapat menjiwai kehidupan masyarakat dan negara, bukan mengutamakan simbol-simbolnya, sebagaimana yang telah dipegang teguh oleh kaum fundamentalis.

Kedua, kekurangan mereka juga terletak pada sikap dan pandangannya yang eksklusif yaitu pandangan yang berkeyakinan bahwa pandangan dan keyakinan merekalah yang paling benar, sedangkan sikap dan pandangan orang lain yang tidak sejalan dengan mereka dianggap salah dan harus dikutuk. Sebagai akibat dari pandangan dan keyakinan yang demikian itu, mereka cenderung 
tertutup, dan tidak mau menerima pandangan dan sikap yang berbeda. Pada intinya, tidak ada jalan baginya untuk berdialog (Nata, 2001: 25).

Ketiga, dari segi budaya dan sosial, kekurangan mereka terlihat pula dalam menyikapi berbagai produk budaya, sungguh pun pada tataran yang sifatnya kultural seperti pakaian, alat-alat keperluan kebersihan; dan lain sebagainya yang bersifat konservatif.

Keempat, dari segi bentuk dan gerakannya, mereka cenderung memaksakan kehendak dengan menggunakan berbagai cara termasuk cara-cara kekerasan, seperti propaganda, hasutan, teror, bahkan pembunuhan, dan sebagainya. Dengan sikap yang demikian, mereka dianggap sebagai kelompok fundamentalis fanatik. Karena beberapa kekurangan tersebut, maka perjuangan Islam fundamentalis dalam menegakkan cita-cita Islam, sering kandas di tengah jalan clan pada akhirnya merugikan dirinya sendiri (Nata, 2001: 26).

Kelima; adanya keyakinan kuat dari kaum fundamentalisis terhadap kebenaran yang mereka perjuangkan. Sikap ini pada saat yang sama dibarengi dengan penafion kebenaran yang melekat pada pihak lain yang akan diganti. Dalam gerakan sosial, keyakinan tentang kebenaran keyakinan atau nilai filosofis yang dianut, sering dikombinasikan dengan cara-cara pencapaian yang mengatasnamakan ideal seperti kerakyatan atau kemanusiaan, akan tetapi disebabkan kuatnya keyakinan tersebut, dapat mengakibatkan munculnya sikap emosional yang men- jurus pada kekerasan (Zada, 2002: 16-17).

Ciri-ciri fundamentalisme sosial di atas dapat dijadikan titik tolak (starting point) untuk memahami fenomena agama. Tentu saja tiga ciri tersebut tidak dapat dijadikan sebagai patokan baku untuk menilai apakah fenomena sebuah agama dapat dikategorikan fundamentalis atau tidak. Ketiganya semata-mata berfungsi sebagai working hypothesis untuk membantu melihat persoalan yang mengandung kemiripankemiripan. Dengan kata lain, jika suatu fenomena keberagamaan hanya memenuhi satu atau dua ciri di atas, bukan berarti ia tidak dapat diasosiasikan dengan fundamentalisme. Sebaliknya, bila fenomena tersebut memiliki kriteria lebih dari tiga, ia juga tidak dapat dikeluarkan dari kategori fundamentalisme. Tentunya kelonggaran ini perlu diberi catatan, yakni bila memang tidak terdapat istilah lain yang mampu menjelaskan fenomena yang terjadi (Zada, 2002: 16-17). 


\section{G. Fenomena Penerimaan Masyarakat terhadap}

\section{Islam Fundamentalis}

Pertanyaan yang perlu dieksplorasi dalam kajian ini adalah, Islam fundamentalis dengan segala kelemahan dan kekurangan yang melekat pada lebel ini, tapi justru kenapa kecendrungan masyarakat melirik bahkan masuk dalam kelompok yang dianggap fundamentalis, taruhlah seperti Hizbut Tahrir Indonesia, Majlis Mujahidin Indonesia, atau Ormas-ormas yang sealiran dengannya?

Dalam konteks kultural, ideologi agama diarahkan untuk menciptakan tatanan masyarakat kontemporer di bawah kedaulatan Tuhan (god's sovereignity), dengan aturan (rule) dan hukum (law) yang digalin dari kitab suci (revealed in scripture). Tatanan yang dimaksud hanya dapat dimanifestasikan melalui pemurnian masyarakat (purifying society) dari pengajaran dan praktik-praktik yang tidak Islam (unislamic theaching and practices) yang selama ini digali dari ideologi Barat sekuler. Pemurnian masyarakat hanya dapat dilakukan satusatunya melalui pengembalian kea rah sumber-sumber murni Islam (Islam's original pure resources) yang digali dari al-Qur'an dan al-Hadis (Jainuri, 2003: 166).

Dalam konteks struktural, agama diarahkan untuk mewujudkan negara Islam modern (an ideal Islam state) sebagaimana pernah diandaikan pada zaman nabi dan para sahabatnya (modeled on that of prophet and his companions). Lebih dari itu, orientasi struktural adalah munculnya pengislaman system sosial dan politik secara total dalam tatanan masyarakat dan negara syariah.

Fenomena kecendrungan masyarakat untuk masuk dalam golongan fundamentalis ini dapat penulis petakan dan analisis dari beberapa aspek;

Pertama, aspek doktrinal, keyakinan akan kebenaran adalah bagian mendasar dalam kehidupan religious individu maupun suatu kelompok. Individu dalam meligitimasi dan melembagakan tindakan fundamental terhadap orang atau kelompok lain tidak hanya didasarkan pada alasan-alasan atau gagasan-gagasan yang bersifat keduniawian yang berada pada tataran pemenuhan hajat akan kekuasaan dan kemewahan materi. 
Aspek doktrinal yang dibentuk oleh lembaga tertentu kepada masyarakat untuk memformat ide, konsep dan gagasan kemudian mengakar dalam pemahaman mereka yang secara umum menjanjikan keselamatan dunia dan akhirat.

Kedua, aspek skeptisisme masyarakat dengan aturan Negara yang tidak menjamin kehidupan yang sejahtera. Dalam aspek ini, kehidupan yang sangat konpleks dengan segala hegemoninya membawa kegersangan hati masyarakat yang hidup di zaman modern ini. Kegelisahan spiritual inilah yang membawa kepada arah orientasi keberagamaan yang memberikan solusi pencerahan hati dan ketenangan. Hal ini sangat memberikan ruang dan waktu bagi masyarakat modern untuk memilih doktrin yang fundamental dan ortodok.

Ketiga, kebencian terhadap Barat dan budayanya. Sejalan dengan itu, Kuntowijoyo menyatakan bahwa fundamentalisme Islam adalah gerakan anti industri, karena industrialisasi dilihat sudah menimbulkan dampak negatif seperti dominasi masa lalu oleh masa kini, dominasi industri atas alam, dan dominasi bangsa atas bangsa lain. Sejalan dengan itu, kaum fundamentalis memiliki karakter pemikiran berikut; Pertama, kaum fundamentalis ingin kembali ke zaman Rasul hampir dalam semua segi. Dalam berpakaian mereka cenderung memakai jubah (untuk laki-laki) dan cadar (untuk perempuan) dengan maksud untuk menolak industri fashion. Tampaknya "kesalahan" yang mereka lakukan ialah menganggap fashion yang bersifat muamalah itu sebagai akidah. Kedua, kaum fundamentalis ingin kembali ke alam (back to nature). Dengan alasan misalnya, untuk menolak wewangian buatan pabrik, kaum fundamentalis memakai bahan-bahan alamiah seperti siwak, minyak wangi tanpa zat alkohol, dan sejenisnya. Kesalahan inipun sama dengan pertama. Ketiga, kaum fundamentalis menampakkan sikap yang memiliki implikasi politik. lni yang menyebabkan negara-negara industri menilai fundamentalisme sama dengan terorisme. Dalam konteks ini pula, negara-negara Barat (terutama Amerika Serikat) melihat Iran, Libya, FAS, Al-Jazair, Somalia, dan Sudan sebagai sarang fundamentalis, sekaligus teroris (Kuntowijoyo, 1997: 49).

Keempat, aspek politik, kaum fundamentalis berpikir dan mendambakan kesadaran politik dalam maknanya yang tepat. Dalam 
konteks itu, mereka berupaya menyadari identitas diri sendiri yang berarti menyadari sepenuhya kekuatan-kekuatan institusional yang telah bekerja pada diri orang itu sendiri. Jalan menuju pembebasan pribadi tidak bersifat privat atau melalui meditasi, tetapi lewat jalur politik. Kesadaran semacam itu berkembang lewat tindakan yang sadar, reflektif, dan tentunya akurat (Novak, 2000: 137).

Berdasarkan aspek-aspek tersebut, menurut analisa penulis yang menyebabkan keberterimaan masyarakat terhadap pemikiran dan gerakan Islam fundamentalis. Analisa penulis seperti ini bisa saja diperkuat dengan aspek-aspek lain di luar aspek yang telah penulis sebutkan, tapi yang dominan adalah seperti aspek doctrinal, aspek skeptisisme, dan politik kebangsaan.

\section{H. Penutup}

Gerakan fundamentalisme dalam Islam umumnya dapat dilihat sebagai respon reaktif terhadap berbagai krisis akibat berkuasa dan kuatnya negara bangsa (the nation -state). Bangkitnya fundamentalisme dalam Islam berkaitan dengan tesis Samuel Huntington (1993) tentang "Clash of Civilization" antara dar Islam yang memuat peradaban berdasarkan prinsip-prinsip agama Islam di satu pihak dan peradaban Yahudi-Kristiani yang membarat di pihak lain. Begitu juga fundamentalisme berkaitan dengan Islam politik yang diidentifikasi sebagai kekuasaan baru dan otentik untuk melakukan perubahan yang positif sesuai format yang islami. Islam dalam perspektif ini dipandang sebagai solusi yang paling efektif dalam menghadapi tumbuhnya secularism dan budaya global yang destruktif.[] 


\section{DAFTAR PUSTAKA}

Al-Qardawi, Yusuf. 2001. Ekstremisme dalam Wacana Islam, Islam Liberal, Pemikiran Islam Kontemporer Tentang Isu-isu Global. Jakarta: Paramadina

Ahmed, Akbar S. 1994. Posmodernisme Bahaya dan Harapan Bagi Islam Bandung: Mizan

Harahap, Syahrin. 1997. Islam Dinamis, Yogyakarta: Tiara Wacana

Esposito, John L. 1992. Myth or Relity The Islamic Threat? Oxford: Oxford University Press

2002. Unholy War, terj. Arif Maftuhin, Yogyakarta: LKIS

Fazlurrahman. 1979. "Islam: Challenges and Oportunities," dalam Altford T.Welch dan Pierre Cachia (ed.), Islam and Past Influence and Present Challenge, London: Edinburgh University Press

1984. Islam and Modernity: Transformation of an Intellectual Tradition. Chicago: The University Press

Jainuri, Ahmad. Dkk., 2003. Terorisme \& Fundamentalis Agama. Malang: Bayumedia Publishing

Kuntawijoyo. 1997. Identitas Politik Umat Islam. Bandung: Mizan

Martin, Marty E., dan R. Scott Appleby, 1993. Introduction: Fundamentalism Observed. Chicago: University of Chicago Press

Munawar-Rahman, Budi. 2001. Islam Pluralis: Wacana Kesetaraan Kaum Beriman. Jakarta: Paramadina

Nata, Abudin, 2001. Peta Keberagamaan Pemikiran Islam di Indonesia. Cet. ke-1. Jakarta: Raja Grafindo Persada

Novak, Michael. 2000. Teologi Politik Fundamentalis. Yogyakarta: Jendela

Shepard, William. 1987. 'Fundamentalism Cristian and Islam', dalam Studies in Religion Vol. 17, 1 
Tibi, Bassam. 2000. Ancaman Fundamentalisme: Rajutan Islam Politik dan Kekacauan Dunia Baru. Yogyakarta: Tiara Wacana

Zada, Khamani. 2002. Islam Fundamentalis Pergulatan Ormas-ormas Islam Garis Keras di Indonesia. Bandung: Teraju 